\title{
The Effectiveness of Online Platforms after the Pandemic: Will Face-to-Face Classes Affect Students' Perception of Their Behavioural Intention (BIU) to Use Online Platforms?
}

\author{
Rana Saeed Al-Maroof ${ }^{1}$, Noha Alnazzawi ${ }^{2}$, Iman A. Akour ${ }^{3}$, Kevin Ayoubi ${ }^{4}$, Khadija Alhumaid ${ }^{5}$, \\ Nafla Mahdi AlAhbabi ${ }^{6}$, Maryam Alnnaimi ${ }^{1}$, Sarah Thabit ${ }^{7}$, Raghad Alfaisal ${ }^{8}$ (D) Ahmad Aburayya 9 (1) \\ and Said Salloum ${ }^{10, *(\mathbb{D})}$
}

1 English Language \& Linguistics Department, Al Buraimi University College, Al Buraimi 512, Oman; rana@buc.edu.om (R.S.A.-M.); maryam@buc.edu.om (M.A.)

2 Department of Computer Science and Engineering, Yanbu University College, Yanbu 30436, Saudi Arabia; alnazzawin@rcyci.edu.sa

3 Information Systems Department, University of Sharjah, Sharjah 26666, United Arab Emirates; aalhamad@sharjah.ac.ae

4 Department of English/General Studies, Khalifa Bin Zayed Air College, Al Ain 295, United Arab Emirates; kayoubi@hct.ac.ae

check for
updates

Citation: Al-Maroof, R.S.;

Alnazzawi, N.; Akour, I.A.; Ayoubi,

K.; Alhumaid, K.; AlAhbabi, N.M.;

Alnnaimi, M.; Thabit, S.; Alfaisal, R.;

Aburayya, A.; et al. The Effectiveness

of Online Platforms after the

Pandemic: Will Face-to-Face Classes

Affect Students' Perception of Their

Behavioural Intention (BIU) to Use

Online Platforms?. Informatics 2021, 8 ,

83. https://doi.org/10.3390/

informatics 8040083

\section{Academic Editors:}

Guendalina Capece, Flavia Di Costa and Francisco José García-Peñalvo

Received: 1 October 2021

Accepted: 22 November 2021

Published: 24 November 2021

Publisher's Note: MDPI stays neutral with regard to jurisdictional claims in published maps and institutional affiliations.

Copyright: (C) 2021 by the authors. Licensee MDPI, Basel, Switzerland. This article is an open access article distributed under the terms and conditions of the Creative Commons Attribution (CC BY) license (https:// creativecommons.org/licenses/by/ $4.0 /)$.
5 College of Education, Zayed University, Abu Dhabi 19282, United Arab Emirates; khadija.alhumaid@zu.ac.ae

6 Training and Professional Department, Emirates Schools Establishment (ESE), Abu Dhabi 971, United Arab Emirates; nafla.alahbabi@ese.gov.ae

7 Linguistic Department, School of Humanities, Universiti Sains Malaysia, Gelugor 11800, Malaysia; sarahthabit@student.usm.my

8 Computing and Creative Industries, Faculty of Art, Universiti Pendidikan Sultan Idris, Tanjong Malim 35900, Malaysia; raghad.alfaisal81@gmail.com

9 Quality \& Corporate Development Office, Dubai Health Authority, Dubai 9115, United Arab Emirates; amaburayya@dha.gov.ae

10 School of Science, Engineering, and Environment, University of Salford, Salford M5 4WT, UK

* Correspondence: salloum78@live.com

Abstract: The purpose of this study is to investigate students' intention to continue using online learning platforms during face-to-face traditional classes in a way that is parallel to their usage during online virtual classes (during the pandemic). This investigation of students' intention is based on a conceptual model that uses newly used external factors in addition to the technology acceptance model (TAM) contrasts; hence, it takes into consideration users' satisfaction, the external factor of information richness (IR) and the quality of the educational system and information disseminated. The participants were 768 university students who have experienced the teaching environments of both traditional face-to-face classes and online classes during the pandemic. A structural equation modelling (SEM) test was conducted to analyse the independent variables, including the users' situation awareness (SA), perceived ease of use, perceived usefulness, satisfaction, IR, education system quality and information quality. An online questionnaire was used to explore students' perceptions of their intention to use online platforms accessibly in a face-to-face learning environment. The results showed that (a) students prefer online platforms that have a higher level of content richness, to be able to implement the three dimensions of users' situation awareness (perception, comprehension and projection); (b) there were significant effects of TAM constructs on students' satisfaction and acceptance; (c) students are in favour of using a learning platform that is characterised by a high level of educational system quality and information quality and (d) students with a higher level of satisfaction have a more positive attitude in their willingness to use the online learning system.

Keywords: information richness; information systems; situation awareness; technology acceptance model; online platform 


\section{Introduction}

In recent years, there has been a tremendous focus on increasing the acceptance of online learning platforms, as these are used as media to create a new educational environment that has features, tools [1-3] and an atmosphere that is rather different from that of traditional classrooms $[4,5]$. This investigation aimed at exploring the impact of certain factors on teachers' and students' perceptions of these online learning platforms [6-9]. During to the pandemic, many countries have faced difficulties in shifting to a digitalised world. This shift would lead to a total change in the educational setting, such as that the students and teachers are in different locations but can still interact with one another $[10,11]$. The situation started to change again after vaccines were made available, and now, most colleges and universities are returning to the traditional classroom. Face-to-face communication will take prevalence once more. This invites a question on the effectiveness of online learning platforms in the future.

Although many studies have tackled the importance of e-learning platforms in educational environments, exploring students' perception [6,12-17], few have investigated the effectiveness of online classes once traditional classes are resumed, with emphasis on the information richness (IR) of the three dimensions of situation awareness (SA). SA can be defined as the perception of information that ensures that users can interpret the content presented in an online class. Then, the comprehension deals with the integration of the information previously absorbed with new information and, finally, the comprehension of the total information made available to achieve the goals of these online classes [18]. Based on the previous assumption, this study aims to examine student and teachers' acceptance of e-learning platforms by:

1. Assessing the quality and the development of e-learning platforms after the pandemic, as they have an impact on students' performance, innovation and SA.

2. Measuring the increased need for e-learning platforms due to their ease of use and usefulness and their impact on academic services, pedagogies and practice for lifelong learning.

SA embraces another dimension that goes beyond perception in order to help users combine, interpret and store information. The perception of information can act as a helpful first step, but the need for the comprehension of the information is crucial. The comprehension has to do with the integration of pieces of information based on the participants' own goals. Projection can be defined as the ability to predict future events that enhance the capability to better understand the new situation [18]. In other words, SA is related to users' ability to take action based on the perception of information that can predict certain future events. Accordingly, SA is related to how environmental elements are perceived, comprehended and predicted $[19,20]$. Perception is the first level in SA, which has to do with the observation of information. This includes examining the dynamics, features and status that are relevant to the situation. The second level of SA is comprehension, where information is processed. The information is integrated to complete the picture from various perspectives. Comprehension leads to a better understanding of the environment. Finally, projection is the third level, where the reaction is built on time. The project helps predict future events and actions in relation to specific situation comprehension [21].

Accordingly, the conceptual model investigates the effectiveness of e-learning platforms from two different perspectives. The first perspective is related to mere acceptance of technology, where the technology acceptance model (TAM) is used to determine the acceptance of the technological aspects of e-learning platforms by examining their usefulness and ease of use. On the other hand, the second perspective focuses on SA, which investigates the effect of the teaching-learning environment on users' level of acceptance.

In short, studies on online learning platforms have relied mostly on the TAM [22], flow theory (FB) and the unified theory on acceptance and use of technology model (UTAUT) to explore the effectiveness of e-learning platforms before and after the pandemic [23,24]. No known study has explored through a conceptual model the intention to use online learning platforms when face-to-face classes are resumed. The model takes into account 
the factor of IR with SA. The theory of SA includes three dimensions, namely perception, comprehension and projection. This study is motivated by the need to fill this knowledge gap. Previous works of research show that TAM constructs and the external factors of enjoyment, familiarity, innovation and personality are all crucially significant in shaping learners' attitudes and perception towards the acceptance of online learning platforms [25-29]. This study is driven by the fact that there is a need to validate the intention to use online learning platforms simultaneously with face-to-face classes in the Gulf area, depending on the conceptual model that comprises TAM constructs and its relation with IR and satisfaction.

\section{Literature Review}

The literature review is divided into two main parts. Each part represents a period where studies were conducted under two completely different sets of circumstances. The first group includes research papers that focus on the effectiveness of e-learning platforms before the pandemic, taking into consideration the fact that face-to-face classes can help as a tool in everyday education. E-learning platforms were used as a secondary tool, and not an essential one, in transmitting information among teachers and learners $[25,30,31]$. The second group of research papers, however, adopted different strategies that stem from the fact that the pandemic imposed certain new restrictions that made face-to-face interaction impossible. One of the striking differences between the two groups is that the studies conducted before the pandemic examined the acceptance of technology before its actual use. Gradually, studies began focusing on the acceptance of e-learning platforms, as they were used in the educational environment during the pandemic $[7,32,33]$. The acceptance and adoption of online learning platforms has been the concern of many researchers starting from 2006. The implementation of different models reflects the urgent need to tackle the impact of this technology on students' and teachers' perceptions and their actual use. The variations of the adopted model reflect the fact that these technologies can be investigated by tackling variant models, including TAM, FB and UTAUT [25,30,34]. An investigation of the effectiveness of any learning platform before the pandemic focused on important external factors such as gender, cultural differences, personality differences, technical support, technology training, equipment accessibility and experience [31,34,35]. Furthermore, the importance of flow theory and perceived enjoyment was also evident from these studies. The main reason for this is that these factors can boost the chances of continuing to use these platforms post pandemic. They can work collaboratively with the other models to give deeper insights and more detailed results on the impact of these factors on the teaching-learning process $[27,30,34]$.

The difficult pandemic days compelled teachers and students to shift from the traditional physical classroom, where face-to-face communication is the most common way of interacting, to a kind of digitalised world that depends on different websites and applications. Studies conducted after the outbreak of the pandemic have tackled the issue of acceptance of online learning platforms depending on different models including TAM, TBP and UTAUT, along with other external factors. These studies have shown that most TAM constructs, especially the perceived ease of use and the perceived usefulness, have a high impact on the intention to use technology during the pandemic [13,32]. On the other hand, other studies have ignored the importance of the TAM constructs by examining performance expectancy (PE), effort expectancy (EE), social influence (SI) and social isolation and their effect on online learning platforms. Studies have proven that there is a huge effect of system quality and information quality on students' perception of the actual use of online platforms [26].

The external factors that are considered crucial and effective for the acceptance of online learning platforms tend to vary. The most important factor is the fear of COVID-19 during the pandemic. In addition, there are other external factors such as perceived risk, satisfaction, attitude and innovation $[13,33,36]$. Surprisingly, the external factors may vary in their level of impact. In a study by [7], the results illustrated that the best predictor for student motivation is enjoyment, which is followed by self-efficacy. In another study 
by [37], less emphasis has been placed on the perceived ease of use in comparison with other TAM constructs.

Finally, it is worth mentioning that these results were obtained from university students with different majors, including tourism and hospitality [6] and accounting [38]. The focus on students as part of the sample owes to the fact that they are attachable to the technology and are the most frequent users of these online platforms. These studies have been conducted in different places worldwide. Some of these studies have shown interesting results by comparing students from different cultural backgrounds, such as Mexico, Peru, Turkey and the USA [33].

In Table 1, through the repeated use of TAM and UTAUT models, it has been proven that these models are influential in investigating users' acceptance or adoption of various technologies, including e-learning platforms in education. The implementation of these theories in business, health, e-commerce and agriculture has emphasised the importance of these models not only in education but also in other fields [39-42]. The emphasis on the adoption of these models is continually growing. In a recent study by [41], the researchers build a model based on TAM 1, TAM2 and TAM3, with the aim of examining the factors that influence Malaysian small and medium enterprises (SMEs) to adopt mobile commerce.

Table 1. Studies before and after the outbreak of the pandemic.

\begin{tabular}{|c|c|c|c|c|}
\hline $\begin{array}{l}\text { Authors and } \\
\text { Dates }\end{array}$ & $\begin{array}{l}\text { Online Learning } \\
\text { Category }\end{array}$ & Model & Type of Study & Results Verification \\
\hline$[30]$ & $\begin{array}{l}\text { Online Learning } \\
\text { System }\end{array}$ & TAM and FB & Adoption & $\begin{array}{l}\text { TAM and TPB can predict e-learning } \\
\text { adoption positively. }\end{array}$ \\
\hline [25] & E-learning Tool & $\begin{array}{l}\text { TAM and the } \\
\text { Innovation Diffusion } \\
\text { Theory }\end{array}$ & Adoption & $\begin{array}{l}\text { TAM, system quality and computer } \\
\text { self-efficacy can positively affect } \\
\text { students' behaviour }\end{array}$ \\
\hline$[34]$ & $\begin{array}{l}\text { Online Learning } \\
\text { System }\end{array}$ & $\begin{array}{c}\text { Perceived } \\
\text { Self-efficacy } \\
\text { Perceived Usefulness } \\
\text { Satisfaction }\end{array}$ & Acceptance & $\begin{array}{l}\text { Perceived self-efficacy and perceived } \\
\text { usefulness have varied effects due to } \\
\text { cultural differences and years of } \\
\text { experience }\end{array}$ \\
\hline$[31]$ & $\begin{array}{l}\text { TAM with a } \\
\text { Self-regulation } \\
\text { Concept. }\end{array}$ & $\begin{array}{l}\text { Online Learning } \\
\text { System }\end{array}$ & Acceptance & $\begin{array}{l}\text { TAM constructs can positively affect } \\
\text { the acceptance of technology; they are } \\
\text { affected by other factors such as } \\
\text { personality differences, technical } \\
\text { support, technology training and } \\
\text { equipment accessibility }\end{array}$ \\
\hline [43] & $\begin{array}{l}\text { TAM and } \\
\text { Satisfaction }\end{array}$ & Online Learning & Acceptance & $\begin{array}{l}\text { TAM constructs may have varied } \\
\text { effects on users' satisfaction in their } \\
\text { acceptance of online learning systems; } \\
\text { gender and diversity have an impact } \\
\text { on TAM constructs. }\end{array}$ \\
\hline [27] & $\begin{array}{l}\text { UTAUT with a } \\
\text { Group of External }\end{array}$ & $\begin{array}{l}\text { Online Learning } \\
\text { System }\end{array}$ & Acceptance & $\begin{array}{l}\text { UTAUT and factors of self-regulation, } \\
\text { computing device ownership and } \\
\text { level of familiarity with } \\
\text { education-related technologies can } \\
\text { positively affect the acceptance of an } \\
\text { online learning system }\end{array}$ \\
\hline$[44]$ & $\begin{array}{l}\text { TAM and External } \\
\text { Factors }\end{array}$ & $\begin{array}{l}\text { Online Learning } \\
\text { System }\end{array}$ & Acceptance & $\begin{array}{l}\text { TAM, computer self-efficacy, } \\
\text { convenience, instructors' } \\
\text { characteristics, instructional design } \\
\text { and technological factors positively } \\
\text { affect the acceptance of technology }\end{array}$ \\
\hline [28] & UTAUT & $\begin{array}{l}\text { Two Online Learning } \\
\text { Environments }\end{array}$ & Acceptance & $\begin{array}{l}\text { The main constructs affect users' } \\
\text { acceptance differently; the model has } \\
\text { to be revisited }\end{array}$ \\
\hline
\end{tabular}


Table 1. Cont.

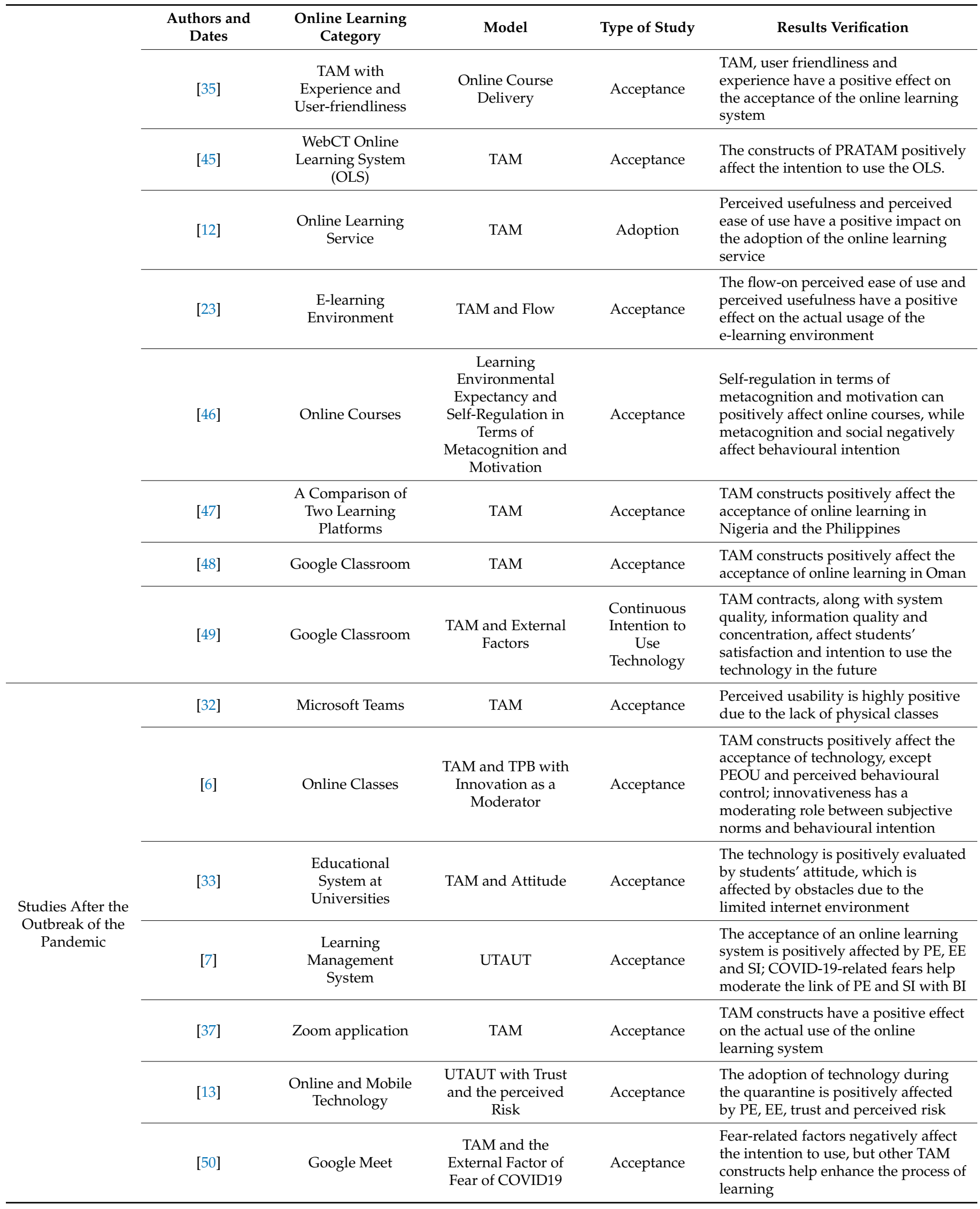


In short, studies conducted before the pandemic focused on certain external factors that may be different from those emphasised by researchers after the outbreak of the pandemic. However, the implementation of TAM and UTAUT as concrete models is evident, assuming that they can measure the acceptance or adoption of online learning platforms effectively and practically. The table below illustrates the main studies conducted before and after the outbreak of the pandemic with respect to the acceptance and adoption of online learning platforms.

\section{Methodology and Research Model}

A research model, as shown in Figure 1, was developed to examine users' intention to use online platforms with seven hypothesised relationships. This research model includes three important dimensions of SA towards IR, which enabled us to explore the effectiveness of these dimensions on the newly formed conceptual model. The level of IR may influence the online learning platform differently. The TAM constructs, along with the educational quality system and information system, add new values in assessing the effectiveness of the online learning platform in relation to IR. Finally, the factor of users' satisfaction can contribute more effectively to the conceptual model and improve users' intention to use the online platform.

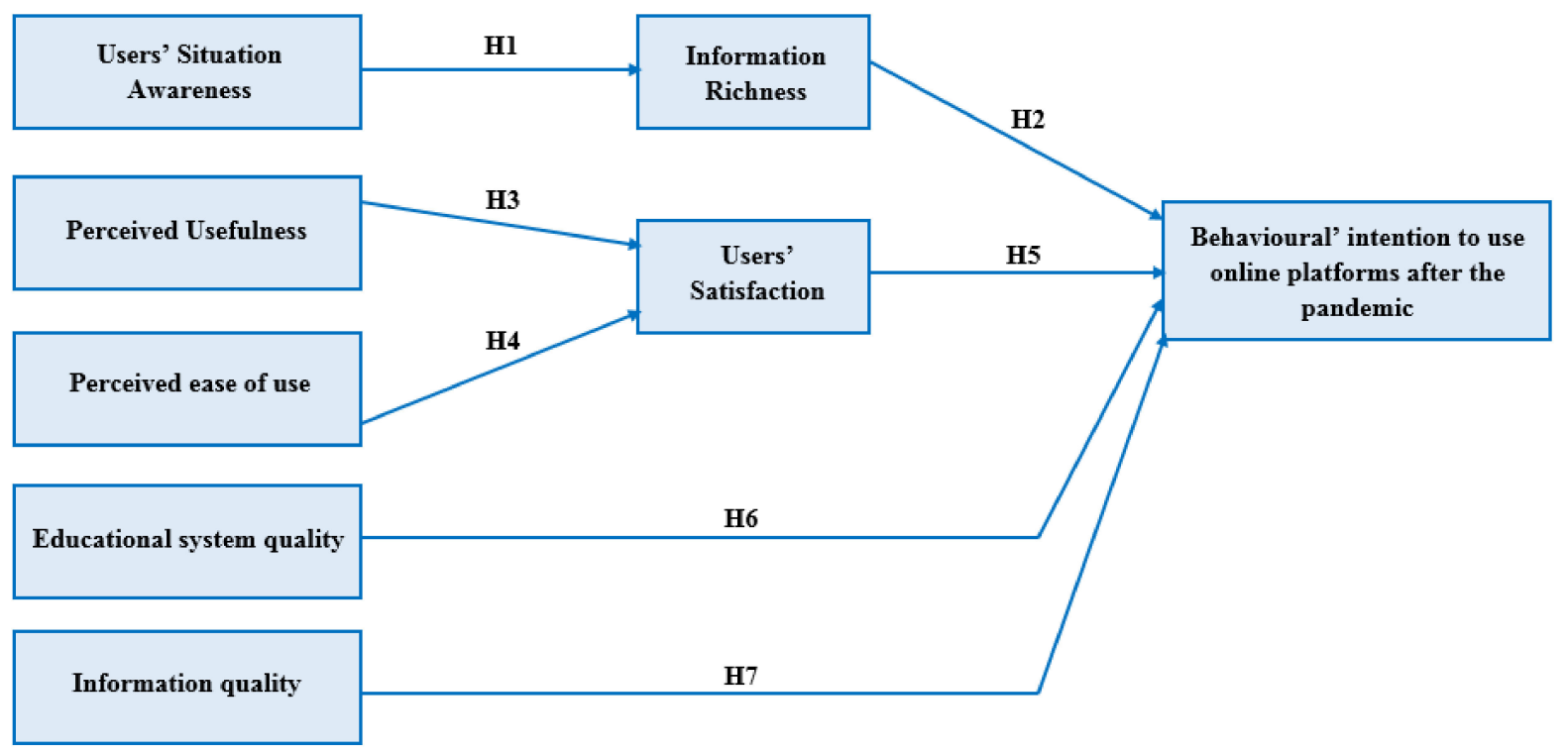

Figure 1. Research model.

\subsection{Situation Awareness and Information Richness}

SA addresses the understanding of what is going on and what might happen next. It has been defined as the ability to develop an accurate internal representation of events in the environment that may lead to successful decision-making. The failure to recognise the importance of SA in a specific environment may lead to conceptual confusion and a degree of conceptual tension [51-53]. Similarly, IR is affected by the environment in the sense that it has a strong impact on individuals' behaviour. When the provided information is sufficient, it can act as a tool to enhance an individual's experience, allowing the development of trust. Accurate IR may lead to the creation of a better teaching-learning environment and increase trust in the technology $[54,55]$.

Information content richness has a close relationship with the quality of the received information with respect to certain aspects, including clarity, relevance, sufficiency, accuracy, timeliness and simplicity. There are various forms that can cover users' choices $[55,56]$. IR is considered a dominant, effective and influential aspect when it comes to online learning platforms, and it has a close relationship with users' personalities, trust and [24,54]. 
IR is related to SA, which is a key factor to understanding how to decide in new situations. SA is governed by the three dimensions of perception, comprehension and projection. Perception is the first important step in formulating a perfect picture of a situation. It is a fundamental aspect, without which it would be impossible to get a clear picture of the importance of the perceived information. Projection can be defined as the ability to predict future events, which enhances the capability to get a better understanding of a new situation. The experience that is accumulated in the process can deeply enhance the forecast of future events [57].

SA embraces another dimension that goes beyond perception to help users combine, interpret and store information. The perception of information can act as a first step, but the need for comprehending the information is crucial. This comprehension has to do with the integration of the pieces of information based on the participants' own goals. Projection can be defined as the ability to predict future events, which enhances the capability to better understand a new situation [18].

This study has created a connection between the effectiveness of IR and the three dimensions of SA, which are perception, comprehension and projection. Whenever the richness in information is evaluated by users to be clear, comprehendible and easily perceptible, the online platform is considered an effective and highly preferred tool. According to the previous assumptions, the following hypotheses are proposed:

Hypothesis 1 (H1). SA positively affects the IR in using online platforms after the pandemic.

Hypothesis 2 (H2). The IR positively affects the use of online platforms after the pandemic.

\subsection{User Satisfaction and TAM Constructs}

User satisfaction is closely related to the users' attitude towards the intention to use technology. According to Dunbar et al. [58], users' satisfaction refers to the impact that an application of technology has on users' attitudes when they are using the technology. Furthermore, Dalvi-Esfahani et al. [59] defined user satisfaction as the type of feeling or pleasure which appears as an outcome of using technology due to its benefits. A similar definition is presented by Dalvi-Esfahani et al. [59], who defines user satisfaction as a subjective evaluation that can be pleasant or unpleasant, proposing that the evaluation appears due to the use of certain technology. Satisfaction has a close relationship with individual attitude, organisation purposes and social consequences. Users' satisfaction is useful in evaluating the effects of online platforms.

On the other hand, perceived ease of use is defined as the degree of effort that users may reflect in using a piece of technology. Whenever the technology is evaluated as effortless, it implies a preference for it, and the intention to use it is evident. Similarly, perceived usefulness is defined as the degree of usefulness that a person derives from a specific system that has a direct effect on his or her performance [60]. Previously, Kaufhold et al. [61] stated clearly that usefulness is the most powerful predictive variable in evaluating information technology usage. The TAM has been used extensively by many studies where usefulness is the key factor in measuring users' intention to use new technology. Both the perceived ease of use and the perceived usefulness are considered influential elements in deterring the effectiveness of technology, and they have a direct effect on users' level of satisfaction. These two constructs are investigated by prior studies to reflect different purposes. For instance, Halimeh et al., and (Krejcie \& Morgan) [62,63] consider TAM constructs as variables that are used to identify the relation between e-wallet and mobile banking with customers' perception. Thus, the following hypotheses are formulated:

Hypothesis 3 (H3). The intention to use an online platform is positively affected by the users' perception of ease of use. 
Hypothesis 4 (H4). The intention to use an online platform is positively affected by the users' perception of usefulness.

Hypothesis $\mathbf{5}$ (H5). The intention to use an online platform is positively affected by users' satisfaction.

\subsection{Educational System Quality and Information Quality}

The educational system entails the use of a particular system due to its easiness, content and enjoyable features. This implies that whenever users evaluate a system, such as a difficulty, it entails that the system will not be functionally acceptable. Online learning platforms are affected by the quality of the education system since it enhances the understanding of the course in an educational atmosphere. The concept of the educational system has been expanded to include ways of developing educational profiles, taking into consideration the benefits and effects of developing and implementing new features. The education quality embraces not only the quality of the system itself functionally, but the quality of the information academically $[64,65]$.

Furthermore, information quality is defined as the quality of the content of the information system, including factors such as the intelligibility, objectivity, sufficiency and relevance of the content. This factor can effectively and exceptionally affect the online learning atmosphere. Whenever the quality is high, students are in favour of using it, leading to positive evaluation by both students and teachers. This is due to the fact that the information is evaluated as sufficient and consistent. The information quality has a relation with the measurement of the excellence of the communication knowledge in content sources assessment [66-68]. Hence, it appears that both the education quality system and information quality can affect the future of online platforms. Therefore, it is hypothesised that:

Hypothesis 6 (H6). The intention to use an online platform is positively affected by the education quality system.

Hypothesis 7 (H7). The intention to use an online platform is positively affected by the information quality.

\section{Research Methodology}

\subsection{Data Collection}

Students studying in UAE universities were sent online surveys to gather data. The period chosen was the fall semester 2020/2021, from 17 February 2021 to 28 April 2021.

One thousand bottom of form (1000) questionnaires were randomly distributed by the researchers. Seven hundred and sixty-eight (768) questionnaires were responded to, indicating a response rate of $77 \%$. Due to missing values, 232 filled questionnaires had to be rejected. As stated by [69], with valid responses for 768, the sample size was maintained as appropriate. This means that for a 1500 population, the respondent sample size was supposed to be 306 . Yet, the sample size used, keeping in mind the minor requirements, was 768 , which is much bigger. For the sample size, the analysis using the structural equation modelling is applicable [70], and this is much needed for hypothesis confirmation. Moreover, present theories have been used to establish the hypotheses; yet, they have been included within the e-learning context. The measurement model has been evaluated by the researchers through the application of SEM (SmartPLS Version 3.2.7, University of South Alabama, Mobile, AL, USA). Advanced treatment has been carried out using the final path model.

\subsection{Study Instrument}

In the current research, the hypothesis has been validated using a survey instrument. Eleven constructs have been measured in the questionnaire. There are 24 items that are 
included in the survey. In Table 2, one can observe the constructs and their source. The applicability of this research study has been enhanced by altering and adjusting earlier research questions.

Table 2. Measurement Items.

\begin{tabular}{|c|c|c|c|}
\hline Constructs & Items & Instrument & Sources \\
\hline \multirow{2}{*}{$\begin{array}{l}\text { Behavioural intention to use } \\
\text { online platforms after the } \\
\text { pandemic }\end{array}$} & BI1 & $\begin{array}{c}\text { I am keen on continuously checking the online } \\
\text { learning platform. }\end{array}$ & \multirow{2}{*}{ [71] } \\
\hline & BI2 & $\begin{array}{l}\text { Overall, I am ready to use an online platform in the } \\
\text { future. }\end{array}$ & \\
\hline \multirow{3}{*}{ Educational system quality } & ESQ1 & $\begin{array}{c}\text { My online learning platform is collaborative and } \\
\text { active. Therefore, I will use it even after the } \\
\text { pandemic. }\end{array}$ & \multirow{3}{*}[72-74]{} \\
\hline & ESQ2 & $\begin{array}{c}\text { My online learning platform has a variety of } \\
\text { learning styles. Therefore, I will use it even after the } \\
\text { pandemic. }\end{array}$ & \\
\hline & ESQ3 & $\begin{array}{c}\text { My online learning platform has an interactive } \\
\text { feature. Therefore, I will use it even after the } \\
\text { pandemic. }\end{array}$ & \\
\hline \multirow{4}{*}{ Information quality } & IQ1 & $\begin{array}{l}\text { My online learning platform provides me with } \\
\text { up-to-date information. Therefore, I will use it even } \\
\text { after the pandemic. }\end{array}$ & \multirow{4}{*}{ [72-74] } \\
\hline & IQ2 & $\begin{array}{l}\text { My online learning platform provides me with the } \\
\text { content I need at the right time. Therefore, I will use } \\
\text { it even after the pandemic. }\end{array}$ & \\
\hline & IQ3 & $\begin{array}{l}\text { My online learning platform provides me with } \\
\text { information that is easy to understand. Therefore, I } \\
\text { will use it even after the pandemic. }\end{array}$ & \\
\hline & IQ4 & $\begin{array}{l}\text { My online learning platform provides me with } \\
\text { organised content/information. Therefore, I will use } \\
\text { it after the pandemic. }\end{array}$ & \\
\hline \multirow{3}{*}{ Information richness } & IR1 & $\begin{array}{l}\text { My full understanding of the online platform urges } \\
\text { me to keep using it after the pandemic. }\end{array}$ & \multirow{3}{*}[75]{} \\
\hline & IR2 & $\begin{array}{c}\text { Using an online platform after the pandemic will } \\
\text { enhance my awareness of learning objectives and } \\
\text { outcomes. }\end{array}$ & \\
\hline & IR3 & $\begin{array}{l}\text { My perception of new material is better if I continue } \\
\text { using online platforms alongside face-to-face classes } \\
\text { after the pandemic. }\end{array}$ & \\
\hline \multirow{3}{*}{ Perceived ease of use } & PEOU1 & $\begin{array}{l}\text { I will continue using online platforms after the } \\
\text { pandemic because it is easy to use them. }\end{array}$ & \multirow{3}{*}[76]{} \\
\hline & PEOU2 & $\begin{array}{l}\text { In my opinion, using an e-learning platform after the } \\
\text { pandemic will be free of effort. }\end{array}$ & \\
\hline & PEOU3 & $\begin{array}{l}\text { Overall, using an online learning platform will be } \\
\text { easy even after the start of the face-to-face classes. }\end{array}$ & \\
\hline \multirow{3}{*}{ Users' situation awareness } & USA1 & $\begin{array}{l}\text { My clear vision of the material offered via online } \\
\text { platforms helps me develop my learning skills. }\end{array}$ & \multirow{3}{*}[57,77,78]{} \\
\hline & USA2 & $\begin{array}{l}\text { Using an online platform after the pandemic will } \\
\text { assist my persuasion and argumentation skills. }\end{array}$ & \\
\hline & USA3 & $\begin{array}{l}\text { My comprehension of new courses will be easier if } \\
\text { online learning is still effective after the pandemic. }\end{array}$ & \\
\hline
\end{tabular}


Table 2. Cont.

\begin{tabular}{|c|c|c|c|}
\hline Constructs & Items & Instrument & Sources \\
\hline \multirow{3}{*}{ Perceived usefulness } & PU1 & $\begin{array}{l}\text { I will continue using online platforms after the } \\
\text { pandemic because they are useful. }\end{array}$ & \multirow{3}{*}{ [76] } \\
\hline & PU2 & $\begin{array}{l}\text { I will continue using online platforms after the } \\
\text { pandemic because they help me complete different } \\
\text { assignments and homework. }\end{array}$ & \\
\hline & PU3 & $\begin{array}{l}\text { I will continue using online platforms after the } \\
\text { pandemic because they help in understanding my } \\
\text { daily classes. }\end{array}$ & \\
\hline \multirow{3}{*}{ Users' satisfaction } & US1 & $\begin{array}{l}\text { I will continue using online platforms after the } \\
\text { pandemic because they satisfy my needs. }\end{array}$ & \multirow{3}{*}{ [79] } \\
\hline & US2 & $\begin{array}{l}\text { I will continue using online platforms after the } \\
\text { pandemic because they resolve my queries when I } \\
\text { miss important information in face-to-face classes. }\end{array}$ & \\
\hline & US3 & $\begin{array}{l}\text { I will continue using online platforms after the } \\
\text { pandemic because it fits my plans. }\end{array}$ & \\
\hline
\end{tabular}

\subsection{Pilot Study of the Questionnaire}

A pilot study was carried out to check the reliability of the questionnaire item. As part of this pilot research, 100 students were randomly selected from the decided population. The entire sample size used in the research for the assessment should be $10 \%$, and keeping this in mind, the sample size was 1000 students. The standard of research was maintained. The findings of the pilot study have been assessed by applying the Cronbach's Alpha (CA) test. It helps recognise the internal reliability through the IBM SPSS Statistics ver. 23 (IBM, Armonk, NY, USA). Hence, for all the measurement items, the conclusions presented were acceptable. The acceptable reliability coefficient is 0.70 when the stated social science research studies are considered [80]. Table 3 states the Cronbach alpha values for the five mentioned measurement scales.

Table 3. Cronbach's alpha values for the pilot study (CA $\geq 0.70)$.

\begin{tabular}{cc}
\hline Constructs & CA \\
\hline BI & 0.760 \\
\hline ESQ & 0.785 \\
\hline IQ & 0.878 \\
\hline IR & 0.817 \\
\hline PEOU & 0.881 \\
\hline USA & 0.889 \\
\hline PU & 0.825 \\
\hline US & 0.816
\end{tabular}

Note: BI is behavioural intention to use online platforms after the pandemic; ESQ is educational system quality; IQ is information quality; IR is information richness; PEOU is perceived ease of use; USA is users' situation awareness; PU is perceived usefulness; US is users' satisfaction.

\subsection{Survey Structure}

The questionnaire survey was given to the students [81]. The survey contained three different sections.

- In the first section, the participant's data are recorded.

- In the second section, two items ask questions related to online learning platforms. 
- In the third section, there are twenty-two items related to educational system quality, information quality, information richness, perceived ease of use, users' situation awareness, perceived usefulness and users' satisfaction. The five-point Likert scale has been used to measure the 24 items. The scale includes strongly disagree (1), disagree (2), neutral (3), agree (4) and strongly agree (5).

\section{Findings and Discussion}

\subsection{Personal/Demographic Information}

In Table 4, the personal/demographic information has been assessed and presented. The male-to-female ratio has been maintained at 40:60. Moreover, 33\% of the respondents were above the age of 29 years, and $67 \%$ of the respondents were between 18 and 29 years in age. An educated background with a university degree was associated with most respondents. In the sample, $65 \%$ of the respondents attained a bachelors' degree, $23 \%$ had a masters' degree and 12\% had a doctorate degree. When respondent access is easy and they volunteer willingly, then the purposive sampling approach should be implemented [82-84]. The research sample was developed using students from various colleges. The age of these students is different and their programs and levels all vary. Furthermore, the IBM SPSS Statistics ver. 23 was applied to measure the demographic data. Table 4 indicates thorough respondent demographic data.

Table 4. Demographic data of the respondents.

\begin{tabular}{cccc}
\hline Criteria & Factor & Frequency & \multicolumn{2}{c}{ Percentage } \\
\hline \multirow{2}{*}{ Gender } & Female & 460 & $60 \%$ \\
\cline { 2 - 4 } & Male & 308 & $40 \%$ \\
\cline { 2 - 4 } Age & Between 18 and 29 & 516 & $67 \%$ \\
\cline { 2 - 4 } & Between 30 and 39 & 137 & $18 \%$ \\
\cline { 2 - 4 } Education & Between 40 and 49 & 32 & $4 \%$ \\
\cline { 2 - 4 } qualification & Between 50 and 59 & 498 & $65 \%$ \\
\cline { 2 - 4 } & Bachelors' & 177 & $23 \%$ \\
\hline
\end{tabular}

\subsection{Data Analysis}

By applying the SmartPLS V.3.2.7 software and the partial least squares-structural equation modelling (PLS-SEM), the research study data analysis was carried out [85]. The collected data were assessed through the application of an assessment approach that has two steps: a structural model and a measurement model [86]. Within the current research, the PLS-SEM has been applied for two reasons.

At first, the most appropriate choice is the PLS-SEM since the current research requires for the existing theory to be built [87]. Second, the PLS-SEM can be applied to efficiently manage the exploratory research attaining complex models [88]. Third, the PLS-SEM does not divide the entire model into fragments but assesses it as a whole [89]. Fourth, the PLS-SEM carries out a concurrent analysis for the measurement and structural model. Hence, the calculations attained are precise [90].

\subsection{Convergent Validity}

The authors [86] recommend that when the measurement model is assessed, the validity, which includes convergent and discriminant validity, and construct reliability, which includes composite reliability (CR), Dijkstra-Henseler's (PA) and CA, should be taken into account. According to Table 5, construct reliability can be determined using CA with values between 0.730 and 0.833 . The threshold value is 0.7 , and the mentioned 
figures are higher [80]. Table 5 also indicates that the CR attains values between 0.770 and 0.904, and these are also higher than 0.7, which is the recommended value [91]. By applying the Dijkstra-Henseler's rho (pA) reliability coefficient, researchers must assess as well as report the construct reliability. Like CR and CA, values of 0.70 or higher should be indicated by the reliability coefficient pA as part of the exploratory research [66]. If the research is expected to be more advanced, then values should be over 0.80 or $0.90[80,92,93]$. It has also been observed in Table 5 that for each measurement construct, the reliability coefficient pA must be over 0.70 . Based on the mentioned results, there is confirmation for construct reliability, and towards the end, the constructs are assumed to be free of error in a sufficient manner. Convergent validity should be measured by testing the average variance extracted (AVE) and factor loading [86]. The findings in Table 4 indicate that the suggested value of 0.7 was always lower than all factor-loading values. Furthermore, according to Table 5, values between 0.540 and 0.758 were produced by AVE, and these are higher than the 0.5 threshold value. Keeping in mind the future results, convergent validity can be attained successfully for all constructs.

Table 5. Convergent validity results that assure acceptable values (factor loading, $C A, C R \geq 0.70$ and AVE $>0.5$ ).

\begin{tabular}{|c|c|c|c|c|c|c|}
\hline Constructs & Items & Factor Loading & CA & CR & PA & AVE \\
\hline \multirow{2}{*}{$\begin{array}{l}\text { Behavioural intention to use online } \\
\text { platforms after the pandemic }\end{array}$} & BI1 & 0.822 & \multirow{2}{*}{0.829} & \multirow{2}{*}{0.897} & \multirow{2}{*}{0.829} & \multirow{2}{*}{0.745} \\
\hline & BI1 & 0.729 & & & & \\
\hline \multirow{3}{*}{ Educational system quality } & ESQ1 & 0.754 & \multirow{3}{*}{0.765} & \multirow{3}{*}{0.844} & \multirow{3}{*}{0.779} & \multirow{3}{*}{0.679} \\
\hline & ESQ2 & 0.733 & & & & \\
\hline & ESQ3 & 0.855 & & & & \\
\hline \multirow{3}{*}{ Information quality } & IQ1 & 0.848 & \multirow{3}{*}{0.778} & \multirow{3}{*}{0.870} & \multirow{3}{*}{0.788} & \multirow{3}{*}{0.692} \\
\hline & IQ2 & 0.777 & & & & \\
\hline & IQ3 & 0.910 & & & & \\
\hline \multirow{3}{*}{ Information richness } & IR1 & 0.859 & \multirow{3}{*}{0.777} & \multirow{3}{*}{0.770} & \multirow{3}{*}{0.653} & \multirow{3}{*}{0.540} \\
\hline & IR2 & 0.904 & & & & \\
\hline & IR3 & 0.891 & & & & \\
\hline \multirow{3}{*}{ Perceived ease of use } & PEOU1 & 0.874 & \multirow{3}{*}{0.803} & \multirow{3}{*}{0.884} & \multirow{3}{*}{0.802} & \multirow{3}{*}{0.717} \\
\hline & PEOU2 & 0.853 & & & & \\
\hline & PEOU3 & 0.822 & & & & \\
\hline \multirow{3}{*}{ Users' situation awareness } & USA1 & 0.771 & \multirow{3}{*}{0.730} & \multirow{3}{*}{0.850} & \multirow{3}{*}{0.738} & \multirow{3}{*}{0.654} \\
\hline & USA2 & 0.828 & & & & \\
\hline & USA3 & 0.890 & & & & \\
\hline \multirow{3}{*}{ Perceived usefulness } & PU1 & 0.781 & \multirow{3}{*}{0.761} & \multirow{3}{*}{0.866} & \multirow{3}{*}{0.770} & \\
\hline & PU2 & 0.858 & & & & 0.609 \\
\hline & PU3 & 0.864 & & & & \\
\hline & US1 & 0.880 & & & & \\
\hline Users' satisfaction & US2 & 0.836 & 0.833 & 0.904 & 0.846 & 0.758 \\
\hline & US3 & 0.871 & & & & \\
\hline
\end{tabular}

\subsection{Discriminant Validity}

Measurement of two criteria, Fornell-Larcker and the Heterotrait-Monotrait ratio (HTMT), has been recommended for the discriminant validity measurement [86]. The outcomes of Table 6 indicate that the requirements of the Fornell-Larcker condition are 
confirmed since the AVEs and their square roots are higher than the rest of the correlation constructs [94].

Table 6. Fornell-Larcker Scale.

\begin{tabular}{ccccccccc}
\hline & BI & ESQ & IQ & IR & PEOU & USA & PU & US \\
\hline BI & $\mathbf{0 . 7 9 8}$ & & & & & & & \\
\hline ESQ & 0.450 & $\mathbf{0 . 8 7 2}$ & & & & & & \\
\hline IQ & 0.692 & 0.363 & $\mathbf{0 . 8 8 5}$ & & & & & \\
\hline IR & 0.626 & 0.538 & 0.296 & $\mathbf{0 . 8 8 0}$ & & & & \\
\hline PEOU & 0.505 & 0.065 & 0.237 & 0.601 & $\mathbf{0 . 8 5 6}$ & & & \\
\hline USA & 0.444 & 0.500 & 0.573 & 0.592 & 0.451 & $\mathbf{0 . 8 1 7}$ & & \\
\hline PU & 0.458 & 0.583 & 0.553 & 0.476 & 0.513 & 0.307 & $\mathbf{0 . 8 5 1}$ & \\
\hline US & 0.446 & 0.565 & 0.641 & 0.616 & 0.604 & 0.391 & 0.521 & $\mathbf{0 . 8 4 4}$
\end{tabular}

Note: BI is behavioural intention to use online platforms after the pandemic; ESQ is educational system quality; IQ is information quality; IR is information richness; PEOU is perceived ease of use; USA is users' situation awareness; PU is perceived usefulness; US is users' satisfaction.

Table 7 indicates the results for the HTMT ratio and shows that, for each construct value, the 0.85 threshold value stays ahead [95]. Therefore, the HTMT ratio is created. Based on the mentioned findings, the discriminant validity is stated. Keeping in mind the results of the analysis, the measurement model assessment did not have any concerns in terms of reliability and validity. Hence, it is possible to assess the structural model by applying the collected data.

Table 7. Heterotrait-Monotrait Ratio (HTMT).

\begin{tabular}{ccccccccc}
\hline & BI & ESQ & IQ & IR & PEOU & USA & PU & US \\
\hline BI & & & & & & & \\
\hline ESQ & 0.232 & & & & & & \\
\hline IQ & 0.202 & 0.517 & & & & & \\
\hline IR & 0.260 & 0.681 & 0.611 & & & & \\
\hline PEOU & 0.506 & 0.633 & 0.609 & 0.333 & & & \\
\hline USA & 0.243 & 0.392 & 0.111 & 0.144 & 0.255 & & \\
\hline PU & 0.501 & 0.658 & 0.753 & 0.511 & 0.721 & 0.512 & \\
\hline US & 0.207 & 0.672 & 0.511 & 0.419 & 0.290 & 0.463 & 0.721 \\
\hline
\end{tabular}

Note: BI is behavioural intention to use online platforms after the pandemic; ESQ is educational system quality; IQ is information quality; IR is information richness; PEOU is perceived ease of use; USA is users' situation awareness; PU is perceived usefulness; US is users' satisfaction.

\subsection{Model Fit}

The fit measures offered by SmartPLS are standard root mean square residual (SRMR), exact fit criteria, d_ULS, d_G, Chi-Square, NFI and RMS_theta, which show the PLS-SEM model fit [96]. The difference present amongst the observed correlations and model implied correlation matrix [88] is denoted by SRMR, and the good model fit measures are values lower than 0.08 [97]. A good model fit is the NFI values that are over 0.90 [98]. The ratio of the proposed model Chi2 value to the benchmark or null model is the NFI [99]. The NFI and parameters have a positive association, which is why the NFI is not considered to be a model fit indicator [88]. The empirical covariance matrix and covariance matrix discrepancy can be observed in two metrics, which are squared Euclidean distance, d_ULS, and the geodesic distance d_G. This has been implied using the composite factor model $[88,100]$. For the reflective model, only the RMS theta is applied, and the correlation degree of the 
outer model residuals is evaluated [99]. The PLS-SEM model is more efficient when the RMS theta value is closer to zero, and it would be a good fit if the value is lower than 0.12. There would be a lack of fit for anything else [101]. With the help of the saturated model, the correlation amongst the constructs is assessed, and the model structure and total effects are observed by the estimated model [88].

According to Table 8, 0.069 is the RMS_theta value, and it shows that the goodnessof-fit for the PLS-SEM model is appropriate enough to indicate the validity of the global PLS model.

Table 8. Model fit indicators.

\begin{tabular}{ccc}
\hline & \multicolumn{2}{c}{ Complete Model } \\
\cline { 2 - 3 } & Saturated Model & Estimated Model \\
\hline SRMR & 0.066 & 0.066 \\
\hline d_ULS & 0.770 & 1.538 \\
\hline d_G & 0.503 & 0.503 \\
\hline Chi-Square & 477.558 & 477.558 \\
\hline NFI & 0.685 & 0.685 \\
\hline Rms Theta & & \\
\hline
\end{tabular}

\subsection{Hypotheses Testing Using PLS-SEM}

Through Smart PLS, it was possible to use the SEM, and maximum likelihood estimation was present to enable the recognition of the interdependence of the structural model and several theoretical constructs [102-106]. Similarly, it was possible to assess the proposed hypotheses. Figure 2 and Table 9 indicate that there is moderate predictive power in the model [107], which means that $55.7 \%$ is the variance percentage for the behavioural intention to use online platforms after the pandemic.

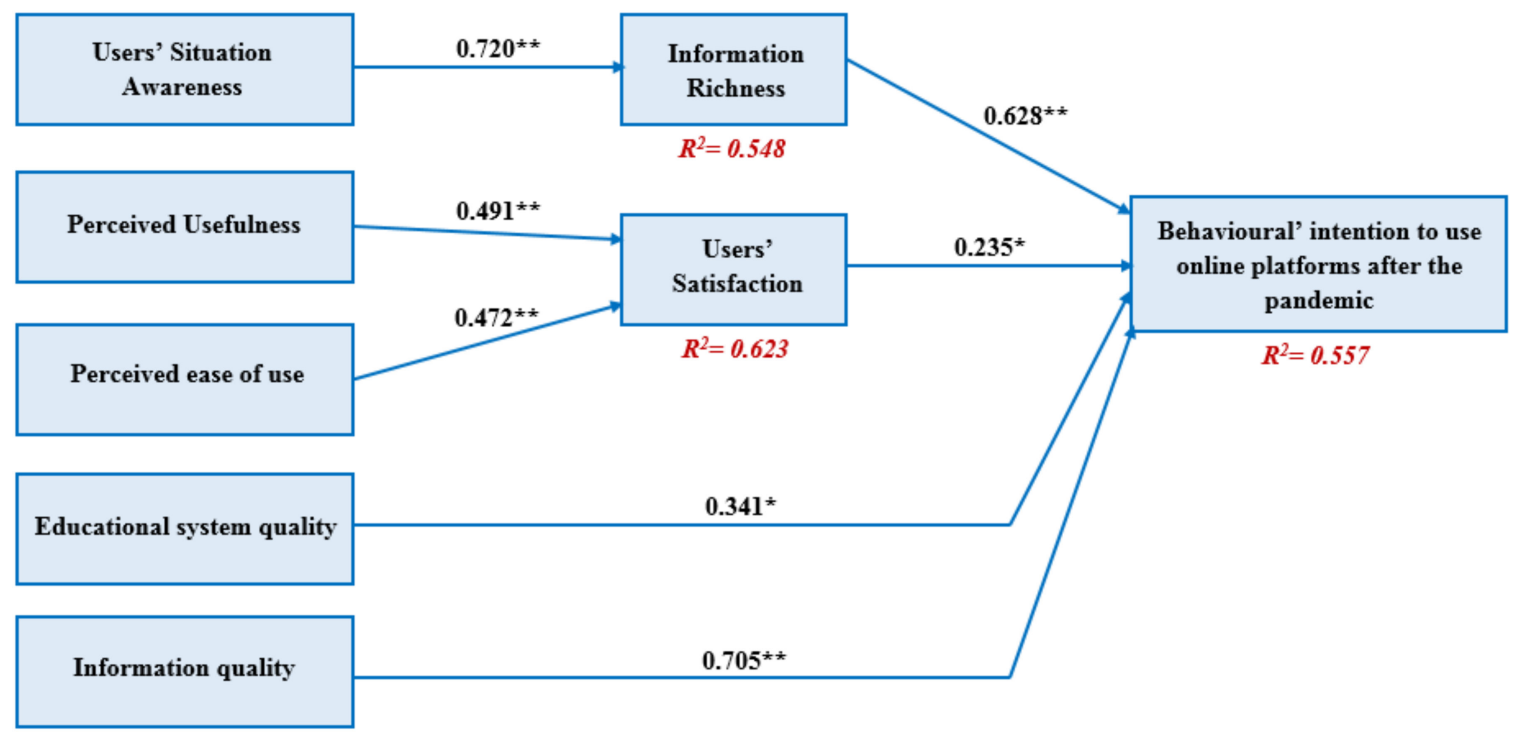

Figure 2. Path coefficient of the model (significant at ${ }^{* *} p \leq 0.01,{ }^{*} p<0.05$ ). 
Table 9. $\mathrm{R}^{2}$ of the endogenous latent variables.

\begin{tabular}{ccl}
\hline Constructs & $\mathbf{R}^{\mathbf{2}}$ & Results \\
\hline BI & 0.557 & Moderate \\
\hline IR & 0.548 & Moderate \\
\hline US & 0.623 & Moderate \\
\hline
\end{tabular}

Note: BI is behavioural intention to use online platforms after the pandemic; information richness, users' satisfaction.

For each stated hypothesis, the beta $(\beta)$ values, $t$-values and $p$-values are stated in Table 10, and these are extracted using the PLS-SEM technique. It has been observed that all the hypotheses have been supported by the researchers. Considering the data assessment, empirical data support the hypotheses $\mathrm{H} 1, \mathrm{H} 2, \mathrm{H} 3, \mathrm{H} 4, \mathrm{H} 5, \mathrm{H} 6$ and $\mathrm{H} 7$. The relationships between users' situation awareness (USA) and information richness (IR) $(\beta=0.720, p<0.001)$ were found to be statistically significant, and thus, hypothesis H1 is generally supported. The results showed that users' satisfaction (US) significantly influences perceived ease of use (PEOU) $(\beta=0.491, p<0.001)$ and perceived usefulness (PU) $(\beta=0.472, p<0.001)$, supporting hypotheses H3 and H4, respectively. Furthermore, information richness (IR), users' satisfaction (US), educational system quality (ESQ) and information quality (IQ) have significant effects on behavioural intention to use online platforms after the pandemic (BI) $(\beta=0.628, p<0.001),(\beta=0.235, p<0.05),(\beta=0.341$, $p<0.05)$ and $(\beta=0.705, p<0.001)$, respectively; hence, $\mathrm{H} 2, \mathrm{H} 5, \mathrm{H} 6$ and $\mathrm{H} 7$ are supported.

Table 10. Hypotheses testing of the research model (significant at ${ }^{* *} p \leq 0.01,{ }^{*} p<0.05$ ).

\begin{tabular}{|c|c|c|c|c|c|c|}
\hline $\mathbf{H}$ & Relationship & Path & $t$-Value & $p$-Value & Direction & Decision \\
\hline $\mathrm{H} 1$ & USA -> IR & 0.720 & 28.657 & 0.000 & Positive & Supported ** \\
\hline $\mathrm{H} 2$ & IR $->$ BI & 0.628 & 10.880 & 0.000 & Positive & Supported ** \\
\hline H3 & PU -> US & 0.491 & 15.489 & 0.000 & Positive & Supported $* *$ \\
\hline $\mathrm{H} 4$ & PEOU -> US & 0.472 & 15.228 & 0.003 & Positive & Supported ** \\
\hline H5 & US -> BI & 0.235 & 3.277 & 0.029 & Positive & Supported * \\
\hline H6 & ESQ -> BI & 0.341 & 3.454 & 0.031 & Positive & Supported * \\
\hline $\mathrm{H7}$ & $\mathrm{IQ}->\mathrm{BI}$ & 0.705 & 8.072 & 0.000 & Positive & Supported ** \\
\hline
\end{tabular}

Note: BI is behavioural intention to use online platforms after the pandemic; ESQ is educational system quality; IQ is information quality; IR is information richness; PEOU is perceived ease of use; USA is users' situation awareness; PU is perceived usefulness; US is users' satisfaction.

\section{Discussion of the Results}

The data analysis has shown that all the seven hypotheses are supported, which empowers our assumptions. The information richness, educational system quality, information quality, satisfaction and TAM constructs have a decisive role in measuring students ${ }^{\prime}$ perception of using online learning platforms. The crucial issues that can be highlighted are related to the association between satisfaction and PEOU and PU on one hand and that between information richness and SA on the other hand, as is explained below.

The current results are in line with prior studies regarding the crucial role of information richness in measuring the intention to use online learning platforms, and they support the awareness situation with the three dimensions of perception, comprehension and projection. These three dimensions play a major role in the acceptance of online platforms [108]. The content richness can enrich the online platform pedagogically by adding the features of interactivity, convenience, instant feedback and social learning. This implies that the higher the content richness is, the more effective the online platform will be [108-110]. 
The secondary result is concerned with the importance of the correlation between users' satisfaction and the two TAM constructs. The higher the degree of perceived ease of use and the perceived usefulness is, the higher the satisfaction level will be. The prior conclusion is consistent with the argument that is proposed by studies from [111-113]. These studies focused on the effectiveness of TAM in different fields such as the agricultural and oil industries and arrived at the conclusion that TAM factors have a varying degree of effectiveness and can significantly affect the acceptance of online learning platforms virtually and practically. The results of the study show that the research model has been validated successfully. The perceived ease of use has a significant effect on the intention of using an online learning platform from students' perspectives. The findings also reveal that perceived usefulness has a significant effect on students' intentions to use this technology and can lead to successive actual use. It explains why students are in favour of constantly using online learning platforms, as they are advantageous in terms of enhancing and facilitating the teaching-learning process.

The third result is concerned with the educational system quality and information quality, which are crucial factors that affect the intention to use online platforms. A student's perception of an online learning platform will be more satisfactory whenever they have a high education quality system and effective information quality [114,115]. Accordingly, system quality will significantly affect the intention to use the online learning platform. The chances to use the online platform will increase if the system is annually improved. This leads to a positive evaluation by students, and it will tremendously affect their perception of the system. In short, when the system quality is improved continuously, it will significantly and positively affect students' perception, especially when the improvement is related to basic features that keep immediate feedback, online communication and accessibility active. The information quality will be affected by such types of improvement, leading to a positive and significant impact on students' perception. The current result is in agreement with previous studies that stated that information quality is considered significant if it satisfies users' needs [116-118]. Both the system quality and information quality of online learning platforms have a significant effect on the intention to use an online learning platform. This result is consistent with $[59,117,119,120]$ and others who stated that the effectiveness of system quality and information quality are significant and the improvement of both will result in more fruitful efforts.

In conclusion, this study has proven that the effectiveness of e-learning platforms will be evident after the pandemic. The fact that e-learning platforms offer ease of use and usefulness will help students and teachers to continue using them even when face-to-face classes are resumed. These two features increase the degree of satisfaction expressed by users. The other variables of SA and information flow have added more advantages to using these platforms. Pedagogical and academic factors are highly affected by the use of these platforms in the educational environment. Finally, when the system quality and the information quality adequately meet the users' needs, the users' perception is improved. Thus, the study has shown that e-learning platforms are influential means of teaching along with traditional classes due to their specific and unique features.

\subsection{Theoretical and Practical Implications}

The results obtained from the current study can serve teachers, students and educational system developers both theoretically and practically. Theoretically speaking, the study provides short and reliable recommendations that may help measure the acceptance level of technology amongst a group of students. Practically speaking, the findings will assist online learning platform developers and designers to provide users with a friendly and fruitful interface where every possible feature can contribute to the teaching-learning environment The effectiveness stems from the fact that they can offer tools and facilities that drive them to seek information by depending on their online learning platform more regularly. 


\subsection{Managerial Implications}

The study confirms that heads of universities and colleges are capable of developing their online learning platform in a way that encourages their users to make use of the system consistently. Based on their proposed assumptions, it is observed that system improvement is fruitful, and this may be beneficial from a marketing and revenue perspective. The findings of the study highlight that the intention to use online learning platforms should be carefully monitored by system managers and the IT-support system.

\subsection{Limitations and Suggestions for Future Studies}

Regardless of our contributions to the literature by creating a comparison of specific models and external factors used in prior studies, outlining the type of technology and technological model, the research study has some limitations. First, the selected studies are limited to a particular group that spans periods of time, one before the pandemic and one after the outbreak of the pandemic. Future studies can extend the period to include studies in the future when the effect of the pandemic declines.

Second, the conceptual model is restricted to factors that affect students' acceptance with respect to information richness, TAM constructs, system quality and information quality. Future studies can include other factors such as attitude, perceived enjoyment, perceived security and perceived addiction.

Third, the samples are limited to a group of students in the Gulf area. Future studies can compare the attitudes of students from the Gulf area and other places such as Malaysia, China, the UK, etc. Hence, the results may vary from the current ones.

Fourth, the obtained results are based on a questionnaire that has close-ended types of questions. Future works should consider using a questionnaire that is qualitative and employ a data collection method that is based on interviews or observations.

Author Contributions: Conceptualization, I.A.A.; formal analysis, M.A. and S.S.; investigation, S.T.; methodology, K.A. (Khadija Alhumaid) and R.A.; project administration, S.S.; resources, N.M.A.; software, N.A.; supervision, K.A. (Kevin Ayoubi); visualization, A.A.; writing-original draft, R.S.A.M.; writing-review and editing, S.S. All authors have read and agreed to the published version of the manuscript.

Funding: This research received no external funding.

Institutional Review Board Statement: Not applicable.

Informed Consent Statement: Not applicable.

Data Availability Statement: The data presented in this study are available on request from the corresponding author.

Conflicts of Interest: The authors declare no conflict of interest.

\section{References}

1. Huang, F.; Sánchez-Prieto, J.C.; Teo, T.; García-Peñalvo, F.J.; Olmos-Migueláñez, S.; Zhao, C. A cross-cultural study on the influence of cultural values and teacher beliefs on university teachers' information and communications technology acceptance. Educ. Technol. Res. Dev. 2021, 69, 1271-1297. [CrossRef]

2. Alsharhan, A.; Salloum, S.A. Using e-learning factors to predict student performance in the practice of precision education. $J$. Legal Ethic. Regul. Issue. 2021, 24, 6.

3. Alsharhan, A.; Salloum, S.; Aburayya, A. Technology acceptance drivers for AR smart glasses in the middle east: A quantitative study. Int. J. Data Netw. Sci. 2022, 6, 193-208. [CrossRef]

4. Hantoobi, S.; Wahdan, A.; Salloum, S.A.; Shaalan, K. Smart Vision of School Classroom. In Proceedings of the Advances in Intelligent Systems and Computing, Cairo, Egypt, 20-22 March 2021; Springer: Singapore, 2021; pp. 525-537.

5. Al-Maroof, R.; Al-Qaysi, N.; Salloum, S.A.; Al-Emran, M. Blended Learning Acceptance: A Systematic Review of Information Systems Models. Technol. Knowl. Learn. 2021, 1-36. [CrossRef]

6. Kim, E.-J.; Kim, J.; Han, S.-H. Understanding Student Acceptance of Online Learning Systems in Higher Education: Application of Social Psychology Theories with Consideration of User Innovativeness. Sustainability 2021, 13, 896. [CrossRef]

7. Raza, S.A.; Qazi, W.; Khan, K.A.; Salam, J. Social Isolation and Acceptance of the Learning Management System (LMS) in the time of COVID-19 Pandemic: An Expansion of the UTAUT Model. J. Educ. Comput. Res. 2021, 59, 183-208. [CrossRef] 
8. Rodriguez-Segura, L.; Zamora-Antuñano, M.A.; Rodríguez-Reséndiz, J.; Paredes-García, W.J.; Altamirano-Corro, J.A.; Cruz-Pérez, M.Á. Teaching challenges in COVID-19 scenery: Teams platform-based student satisfaction approach. Sustainability 2020, 12, 7514. [CrossRef]

9. Zamora-Antuñano, M.A.; Rodríguez-Reséndiz, J.; Rodriguez Segura, L.; Ángel Cruz Pérez, M. Analysis of Emergency Remote Education in COVID-19 Crisis Focused on the Perception of the Teachers. Sustainability 2021, 13, 3820. [CrossRef]

10. Bartley, S.J.; Golek, J.H. Evaluating the cost effectiveness of online and face-to-face instruction. J. Educ. Technol. Soc. 2004, 7, 167-175.

11. Singh, V.; Thurman, A. How Many Ways Can We Define Online Learning? A Systematic Literature Review of Definitions of Online Learning (1988-2018). Am. J. Distance Educ. 2019, 33, 289-306. [CrossRef]

12. Ayodele, T.; Ogunjuyigbe, A.; Odigie, O.; Munda, J. A multi-criteria GIS based model for wind farm site selection using interval type-2 fuzzy analytic hierarchy process: The case study of Nigeria. Appl. Energy 2018, 228, 1853-1869. [CrossRef]

13. Chayomchai, A.; Phonsiri, W.; Junjit, A.; Boongapim, R.; Suwannapusit, U. Factors affecting acceptance and use of online technology in Thai people during COVID-19 quarantine time. Manag. Sci. Lett. 2020, 10, 3009-3016. [CrossRef]

14. AlHamad, A.Q.; Al Qawasmi, K.I. Building an Ethical Framework for E-learning Management System at a University Level. J. Eng. Econ. Dev. 2014, 1, 11.

15. AlHamad, A.Q.; Yaacob, N.; Al-Omari, F. Applying JESS rules to personalize Learning Management System (LMS) using online quizzes. In Proceedings of the 2012 15th International Conference on Interactive Collaborative Learning (ICL), Villach, Austria, 26-28 September 2012; pp. 1-4.

16. Al Hamad, A.Q. Students' perception of implementing a Smart Learning System (SLS) based on Moodle at Fujairah College. In Proceedings of the 2016 13th International Conference on Remote Engineering and Virtual Instrumentation (REV), Madrid, Spain, 24-26 February 2016; pp. 315-318.

17. Salloum, S.A.; Al-Emran, M.; Habes, M.; Alghizzawi, M.; Ghani, M.A.; Shaalan, K. What Impacts the Acceptance of E-learning Through Social Media? An Empirical Study. Recent Adv. Technol. Accept. Model. Theor. 2021, 419-431.

18. Endsley, M.R.; Garland, D.J. Situation Awareness Analysis and Measurement; CRC Press: Boca Raton, FL, USA, 2000.

19. Krems, J.F.; Baumann, M.R.K. Driving and Situation Awareness: A Cognitive Model of Memory-Update Processes. In Proceedings of the Lecture Notes in Computer Science, Orlando, FL, USA, 9-14 July 2009; Springer: Singapore, 2009; pp. 986-994.

20. Nine, J.; Manoharan, S.; Hardt, W. Concept of the comprehension level of situation awareness using an expert system. IOP Conf. Series Mater. Sci. Eng. 2021, 1019, 012103. [CrossRef]

21. Kaur, J.; Kumar, D. Pixel-Oriented Technique: A technique to visualize multidimensional data. Int. J. Comput. Bus. Res. 2012, 2229-6166.

22. Sánchez-Prieto, J.C.; Hernández-García, Á.; García-Peñalvo, F.J.; Chaparro-Peláez, J.; Olmos-Migueláñez, S. Break the walls! Second-Order barriers and the acceptance of mLearning by first-year pre-service teachers. Comput. Hum. Behav. 2019, 95, 158-167. [CrossRef]

23. Esteban-Millat, I.; Martínez-López, F.J.; Pujol-Jover, M.; Gázquez-Abad, J.C.; Alegret, A. An extension of the technology acceptance model for online learning environments. Interact. Learn. Environ. 2018, 26, 895-910. [CrossRef]

24. Al-Maroof, R.S.; Alhumaid, K.; Alhamad, A.Q.; Aburayya, A.; Salloum, S. User Acceptance of Smart Watch for Medical Purposes: An Empirical Study. Futur. Internet 2021, 13, 127. [CrossRef]

25. Tung, F.-C.; Chang, S.-C. Nursing students' behavioral intention to use online courses: A questionnaire survey. Int. J. Nurs. Stud. 2008, 45, 1299-1309. [CrossRef]

26. Chang, S.-C.; Tung, F.-C. An empirical investigation of students' behavioural intentions to use the online learning course websites. Br. J. Educ. Technol. 2007, 39, 71-83. [CrossRef]

27. Ngampornchai, A.; Adams, J. Students' acceptance and readiness for E-learning in Northeastern Thailand. Int. J. Educ. Technol. High. Educ. 2016, 13, 4. [CrossRef]

28. Pedrotti, M.; Nistor, N. User Motivation and Technology Acceptance in Online Learning Environments. In Proceedings of the Lecture Notes in Computer Science, Lyon, France, 13-16 September 2016; Springer: Singapore, 2016; pp. $472-477$.

29. Al-Maroof, R.S.; Alhumaid, K.; Salloum, S. The Continuous Intention to Use E-Learning, from Two Different Perspectives. Educ. Sci. 2020, 11, 6. [CrossRef]

30. Guriting, P.; Ndubisi, N.O. Borneo online banking: Evaluating customer perceptions and behavioural intention. Manag. Res. News 2006, 29, 6-15. [CrossRef]

31. Tabak, F.; Nguyen, N.T. Technology acceptance and performance in online learning environments: Impact of self-regulation. Technology 2013, 9, 116-130.

32. Pal, D.; Vanijja, V. Perceived usability evaluation of Microsoft Teams as an online learning platform during COVID-19 using system usability scale and technology acceptance model in India. Child. Youth Serv. Rev. 2020, 119, 105535. [CrossRef]

33. Aguilera-Hermida, A.P. College students' use and acceptance of emergency online learning due to COVID-19. Int. J. Educ. Res. Open 2020, 1, 100011. [CrossRef]

34. Lee, J.-W.; Mendlinger, S. Perceived Self-Efficacy and Its Effect on Online Learning Acceptance and Student Satisfaction. J. Serv. Sci. Manag. 2011, 04, 243-252. [CrossRef]

35. Wingo, N.P.; Ivankova, N.V.; Moss, J.A. Faculty Perceptions about Teaching Online: Exploring the Literature Using the Technology Acceptance Model as an Organizing Framework. Online Learn. 2017, 21, 15-35. [CrossRef] 
36. Al-Maroof, R.S.; Salloum, S.A.; AlHamad, A.; Shaalan, K.A. Understanding an Extension Technology Acceptance Model of Google Translation: A Multi-Cultural Study in United Arab Emirates. Int. J. Interact. Mob. Technol. (iJIM) 2020, 14, 157-178. [CrossRef]

37. Faisal, R.A.; Jobe, M.C.; Ahmed, O.; Sharker, T. Mental Health Status, Anxiety, and Depression Levels of Bangladeshi University Students During the COVID-19 Pandemic. Int. J. Ment. Heal. Addict. 2021, 1-16. [CrossRef] [PubMed]

38. Lazim, C.S.L.M.; Ismail, N.D.B.; Tazilah, M.D.A.K. Application Of Technology Acceptance Model (Tam) Towards Online Learning During Covid-19 Pandemic: Accounting Students Perspective. Int. J. Bus. Econ. Law. 2021, 24, 13-20.

39. Kayali, M.; Alaaraj, S. Adoption of Cloud Based E-learning in Developing Countries: A Combination A of DOI, TAM and UTAUT. Int. J. Contemp. Manag. Inf. Technol. 2020, 1, 1-7.

40. Ammenwerth, E. Technology acceptance models in health informatics: TAM and UTAUT. Stud. Health Technol. Inf. 2019, 263, 64-71.

41. Salimon, M.G.; Kareem, O.; Mokhtar, S.S.M.; Aliyu, O.A.; Bamgbade, J.A.; Adeleke, A.Q. Malaysian SMEs m-commerce adoption: TAM 3, UTAUT 2 and TOE approach. J. Sci. Technol. Policy Manag. 2021. [CrossRef]

42. Dongsheng, L.I.; Yulian, Y. Research on Farmers' Adoption Intention to E-Commerce of Agricultural Products Based on UTAUT Model. Converter 2021, 2021, 947-957.

43. Al-Azawei, A.; Lundqvist, K. Learner differences in perceived satisfaction of an online learning: An extension to the technology acceptance model in an Arabic sample. Electron. J. E-Learn. 2015, 13, 412-430.

44. Hussein, R.; Aditiawarman, U.; Mohamed, N. E-learning acceptance in a developing country: A case of the Indonesian Open University. In Proceedings of the German E-Science Conference 2007, Baden-Baden, Germany, 2-4 May 2007.

45. Sivo, S.A.; Ku, C.-H.; Acharya, P. Understanding how university student perceptions of resources affect technology acceptance in online learning courses. Australas. J. Educ. Technol. 2018, 34. [CrossRef]

46. Larmuseau, C.; Desmet, P.; Depaepe, F. Perceptions of instructional quality: Impact on acceptance and use of an online learning environment. Interact. Learn. Environ. 2019, 27, 953-964. [CrossRef]

47. Oluyinka, S.; Endozo, A.N.; Daenos, R.G. Impediments to Acceptance of Online Learning in Two Developing International Locations. In Proceedings of the 2019 11th International Conference on Education Technology and Computers, Amsterdam, The Netherlands, 28-31 October 2019; ACM Press: New York, NY, USA, 2019; pp. 127-131.

48. Al-Maroof, R.A.S.; Al-Emran, M. Students Acceptance of Google Classroom: An Exploratory Study using PLS-SEM Approach. Int. J. Emerg. Technol. Learn. 2018, 13, 112-123. [CrossRef]

49. Al-Maroof, R.S.; Alfaisal, A.M.; Salloum, S.A. Google glass adoption in the educational environment: A case study in the Gulf area. Educ. Inf. Technol. 2021, 26, 2477-2500. [CrossRef]

50. Al-Maroof, R.S.; Salloum, S.A.; Hassanien, A.E.; Shaalan, K. Fear from COVID-19 and technology adoption: The impact of Google Meet during Coronavirus pandemic. Interact. Learn. Environ. 2020, 1-16. [CrossRef]

51. Walshe, N.; Ryng, S.; Jonathan, D.; O'Connor, P.; O’Brien, S.; Crowley, C.; Hegarty, J. Situation awareness and the mitigation of risk associated with patient deterioration: A meta-narrative review of theories and models and their relevance to nursing practice. Int. J. Nurs. Stud. 2021, 124, 104086. [CrossRef] [PubMed]

52. Klein, G.; Calderwood, R.; Clinton-Cirocco, A. Rapid Decision Making on the Fire Ground: The Original Study Plus a Postscript. J. Cogn. Eng. Decis. Mak. 2010, 4, 186-209. [CrossRef]

53. Schulz, C.M.; Krautheim, V.; Hackemann, A.; Kreuzer, M.; Kochs, E.F.; Wagner, K.J. Situation awareness errors in anesthesia and critical care in 200 cases of a critical incident reporting system. BMC Anesthesiol. 2015, 16, 1-10. [CrossRef] [PubMed]

54. Wu, J.-J.; Khan, H.A.; Chien, S.-H.; Wen, C.-H. Effect of customization, core self-evaluation, and information richness on trust in online insurance service: Intelligent agent as a moderating variable. Asia Pac. Manag. Rev. 2021. [CrossRef]

55. Galdolage, B.S. Prominence of Information Richness in Accepting Online Based Self-Service Technologies. Arch. Curr. Res. Int. 2021, 31-42. [CrossRef]

56. Yuniar, A.; Fibrianto, A. How virtual fancy things build self-presentation? Consumer's acceptance and use of e-commerce. In Development, Social Change and Environmental Sustainability; CRC Press: Boca Raton, FL, USA, 2021; pp. 123-127.

57. Jones, D.G.; Endsley, M.R. Sources of situation awareness errors in aviation. Aviat. Space, Environ. Med. $1996,67$.

58. Doll, W.J.; Torkzadeh, G. The Measurement of End-User Computing Satisfaction. MIS Q. 1988, 12, 259. [CrossRef]

59. Seddon, P.; Kiew, M.-Y. A Partial Test and Development of Delone and Mclean's Model of IS Success. Australas. J. Inf. Syst. 1996, 4. [CrossRef]

60. Davis, F.D. Perceived Usefulness, Perceived Ease of Use, and User Acceptance of Information Technology. MIS Q. 1989, 13, 319-340. [CrossRef]

61. Davis, F.D.; Bagozzi, R.P.; Warshaw, P.R. User acceptance of computer technology: A comparison of two theoretical models. Manage. Sci. 1989, 35, 982-1003. [CrossRef]

62. Malik, A.N.A.; Annuar, S.N.S. The Effect of Perceived Usefulness, Perceived Ease of Use, Reward, and Perceived Risk toward E-Wallet Usage Intention. In Eurasian Studies in Business and Economics; Springer: Singapore, 2021; pp. 115-130.

63. Prastiawan, D.I.; Aisjah, S.; Rofiaty, R. The Effect of Perceived Usefulness, Perceived Ease of Use, and Social Influence on the Use of Mobile Banking through the Mediation of Attitude Toward Use. Asia Pac. Manag. Bus. Appl. 2021, 009, 243-260. [CrossRef]

64. Dunbar, R.L.; Dingel, M.J.; Dame, L.F.; Winchip, J.; Petzold, A.M. Student social self-efficacy, leadership status, and academic performance in collaborative learning environments. Stud. High. Educ. 2018, 43, 1507-1523. [CrossRef] 
65. Dalvi-Esfahani, M.; Leong, L.W.; Ibrahim, O.; Nilashi, M. Explaining Students' Continuance Intention to Use Mobile Web 2.0 Learning and Their Perceived Learning: An Integrated Approach. J. Educ. Comput. Res. 2020, 57, 1956-2005. [CrossRef]

66. Shan, Y. How credible are online product reviews? The effects of self-generated and system-generated cues on source credibility evaluation. Comput. Hum. Behav. 2016, 55, 633-641. [CrossRef]

67. Kaufhold, M.-A.; Bayer, M.; Reuter, C. Rapid relevance classification of social media posts in disasters and emergencies: A system and evaluation featuring active, incremental and online learning. Inf. Process. Manag. 2020, 57, 102132. [CrossRef]

68. Halimeh, A.A.; Pourghomi, P.; Safieddine, F. The impact of Facebook's news Fact-Checking on information quality (IQ) shared on social media. In Proceedings of the MIT International Conference on Information Quality, Little Rock, AR, USA, 6-7 October 2017.

69. Krejcie, R.V.; Morgan, D.W. Determining Sample Size for Research Activities. Educ. Psychol. Meas. 1970, 30, 607-610. [CrossRef]

70. Chuan, C.L.; Penyelidikan, J. Sample size estimation using Krejcie and Morgan and Cohen statistical power analysis: A comparison. J. Penyelid. IPBL 2006, 7, 78-86.

71. Venkatesh, V.; Morris, M.G.; Davis, G.B.; Davis, F.D. User acceptance of information technology: Toward a unified view. MIS Q. 2003, 27, 425-478. [CrossRef]

72. Hassanzadeh, A.; Kanaani, F.; Elahi, S. A model for measuring e-learning systems success in universities. Expert Syst. Appl. 2012, 39, 10959-10966. [CrossRef]

73. Mehrolia, S.; Alagarsamy, S.; Sabari, M.I. Moderating effects of academic involvement in web-based learning management system success: A multigroup analysis. Heliyon 2021, 7, e07000. [CrossRef]

74. Al-Fraihat, D.; Joy, M.; Masa'Deh, R.; Sinclair, J. Evaluating E-learning systems success: An empirical study. Comput. Hum. Behav. 2020, 102, 67-86. [CrossRef]

75. Power, R.; Forte, D. Case Study: A bold new approach to awareness and education, and how it met an ignoble fate. Comput. Fraud. Secur. 2006, 2006, 7-10. [CrossRef]

76. Davis, F.D. A Technology Acceptance Model for Empirically Testing New End-User Information Systems: Theory and Results; Massachusetts Institute of Technology: Cambridge, MA, USA, 1985.

77. Poindexter, D. Security awareness and the persuasion of managers. Comput. Secur. 1995, 1, 27.

78. Endsley, M.R. Theoretical Underpinnings. In Situation Awareness Analysis and Measurement; Talylor Francis Group: Abingdon, UK, 2000; Chapter 1.

79. Mansoori, E.; Baradaran-Kazem-Zadeh, R. Determining the factors affecting e-customer satisfaction. In Proceedings of the 5th International Conference on Industrial Engineering; Springer: Cham, Switzerland; pp. 1-17.

80. Nunnally, J.C.; Bernstein, I.H. Psychometric Theory; Tata McGraw-Hill Education: New York, NY, USA, 1978.

81. Al-Emran, M.; Salloum, S. Students' Attitudes Towards the Use of Mobile Technologies in e-Evaluation. Int. J. Interact. Mob. Technol. (iJIM) 2017, 11, 195-202. [CrossRef]

82. Alghizzawi, M.; Ghani, M.A.; Som, A.P.M.; Ahmad, M.F.; Amin, A.; Abu Bakar, N.; Salloum, S.A.; Habes, M. The Impact of Smartphone Adoption on Marketing Therapeutic Tourist Sites in Jordan. Int. J. Eng. Technol. 2018, 7, 91-96. [CrossRef]

83. Alshurideh, S.; Al Kurdi, M.; Abumari, B.; Salloum, A. Pharmaceutical Promotion Tools Effect on Physician's Adoption of Medicine Prescribing: Evidence from Jordan. Mod. Appl. Sci. 2018, 12, 210-222. [CrossRef]

84. Habes, M.; Salloum, S.A.; Alghizzawi, M.; Mhamdi, C. The Relation Between Social Media and Students' Academic Performance in Jordan: YouTube Perspective. In Advances in Intelligent Systems and Computing; Springer: Singapore, 2019 ; pp. $382-392$.

85. Ringle, C.M.; Wende, S.; Becker, J.-M. SmartPLS 3; SmartPLS, GmbH: Boenningstedt, Germany, 2015.

86. Hair, J.; Hollingsworth, C.L.; Randolph, A.B.; Chong, A.Y.L. An updated and expanded assessment of PLS-SEM in information systems research. Ind. Manag. Data Syst. 2017, 117, 442-458. [CrossRef]

87. Urbach, N.; Ahlemann, F. Structural equation modeling in information systems research using partial least squares. J. Inf. Technol. Theory Appl. 2010, 11, 5-40.

88. Hair, J.F., Jr.; Hult, G.T.M.; Ringle, C.; Sarstedt, M. A Primer on Partial Least Squares Structural Equation Modeling (PLS-SEM); Sage Publications: Thousand Oaks, CA, USA, 2016.

89. Goodhue, D.L.; Lewis, W.; Thompson, R. Does PLS have adavantages for small sample size or non-normal data? MIS Quaterly 2012, 36, 981-1001. [CrossRef]

90. Barclay, D.; Higgins, C.; Thompson, R. The Partial Least Squares (PLS) Approach to Casual Modeling: Personal Computer Adoption Ans Use as an Illustration. Technol. Stud. 1995, 2, 285-309.

91. Kline, R.B. Principles and Practice of Structural Equation Modeling, 4th ed.; Guilford Press: New York, NY, USA, 2016 ; p. 534.

92. Hair, J.F.; Ringle, C.M.; Sarstedt, M. PLS-SEM: Indeed a Silver Bullet. J. Mark. Theory Pract. 2011, 19, 139-152. [CrossRef]

93. Henseler, J.; Ringle, C.M.; Sinkovics, R.R. The use of partial least squares path modeling in international marketing. In Advances in International Marketing; Sinkovics, R.R., Ghauri, P.N., Eds.; Emerald Group Publishing Limited: Bradford, UK, 2009 ; pp. $277-319$. [CrossRef]

94. Fornell, C.; Larcker, D.F. Evaluating Structural Equation Models with Unobservable Variables and Measurement Error. J. Mark. Res. 1981, 18, 39-50. [CrossRef]

95. Henseler, J.; Ringle, C.M.; Sarstedt, M. A new criterion for assessing discriminant validity in variance-based structural equation modeling. J. Acad. Mark. Sci. 2015, 43, 115-135. [CrossRef]

96. Trial, D. Model Fit. Available online: https://www.smartpls.com/documentation/algorithms-and-techniques/model-fit (accessed on 1 October 2021). 
97. Hu, L.; Bentler, P.M. Fit indices in covariance structure modeling: Sensitivity to underparameterized model misspecification. Psychol. Methods 1998, 3, 424. [CrossRef]

98. Bentler, P.M.; Bonett, D.G. Significance tests and goodness of fit in the analysis of covariance structures. Psychol. Bull. 1980, 88, 588. [CrossRef]

99. Lohmöller, J.B. Latent Variable Path Modeling with Partial Least Squares; Physica-Verlag: Heidelberg, Germany, 1989.

100. Dijkstra, T.K.; Henseler, J. Consistent and asymptotically normal PLS estimators for linear structural equations. Comput. Stat. Data Anal. 2015, 81, 10-23. [CrossRef]

101. Henseler, J.; Dijkstra, T.K.; Sarstedt, M.; Ringle, C.M.; Diamantopoulos, A.; Straub, D.W.; Ketchen, D.J.; Hair, J.F.; Tomas, G.; Hult, M.; et al. Common beliefs and reality about PLS: Comments on Rönkkö and Evermann (2013). Organ. Res. Methods 2014, 17, 182-209. [CrossRef]

102. Al-Emran, M.; Arpaci, I.; Salloum, S.A. An empirical examination of continuous intention to use m-learning: An integrated model. Educ. Inf. Technol. 2020, 25, 2899-2918. [CrossRef]

103. Salloum, S.A.; Alhamad, A.Q.M.; Al-Emran, M.; Monem, A.A.; Shaalan, K. Exploring Students' Acceptance of E-Learning Through the Development of a Comprehensive Technology Acceptance Model. IEEE Access 2019, 7, 128445-128462. [CrossRef]

104. Al-Maroof, R.S.; Akour, I.; Aljanada, R.; Alfaisal, A.M.; Alfaisal, R.M.; Aburayya, A.; Salloum, S.A. Acceptance determinants of 5G services. Int. J. Data Netw. Sci. 2021, 5, 613-628. [CrossRef]

105. Alhumaid, K.; Habes, M.; Salloum, S.A. Examining the Factors Influencing the Mobile Learning Usage During COVID-19 Pandemic: An Integrated SEM-ANN Method. IEEE Access 2021, 9, 102567-102578. [CrossRef]

106. Al-Maroof, R.; Alhumaid, K.; Akour, I.; Salloum, S. Factors That Affect E-Learning Platforms after the Spread of COVID-19: Post Acceptance Study. Data 2021, 6, 49. [CrossRef]

107. Chin, W.W. The partial least squares approach to structural equation modeling. Mod. Methods Bus. Res. 1998, 295, $295-336$.

108. Shaw, R.; Chen, C.C.; Harris, A.L.; Huang, H.-J. The impact of information richness on information security awareness training effectiveness. Comput. Educ. 2009, 52, 92-100. [CrossRef]

109. Daft, R.L.; Lengel, R.H. Information Richness. A New Approach to Managerial Behavior and Organization Design; Defense Technical Information Center (DTIC): Fort Belvoir, VA, USA, 1983.

110. Lo, S.-K.; Lie, T. Selection of communication technologies-A perspective based on information richness theory and trust. Technovation 2008, 28, 146-153. [CrossRef]

111. Legiawan, M.K.; Sutoni, A. Mujiarto The Role of Using Gadgets in Facing the Existence of Information Systems in the Tourism Village Community in Cidadap Village Using TAM (Technology Acceptance Model). J. Phys. Conf. Ser. 2021, $1764,012196$. [CrossRef]

112. Jimenez, I.A.C.; García, L.C.C.; Violante, M.G.; Marcolin, F.; Vezzetti, E. Commonly Used External TAM Variables in e-Learning, Agriculture and Virtual Reality Applications. Futur. Internet 2020, 13, 7. [CrossRef]

113. Hawash, B.; Mokhtar, U.A.; Yusof, Z.M. Users' acceptance of an electronic record management system in the context of the oil and gas sector in Yemen: An application of ISSM-TAM. Int. J. Manag. Enterp. Dev. 2021, 20, 75-98. [CrossRef]

114. Effendy, F.; Kurniawati, O.D.; Priambada, G. Factor Affecting E-Learning User Acceptance: A Case Study of AULA. J. Physics Conf. Ser. 2021, 1783, 012122. [CrossRef]

115. Basurra, S.; Bamansoor, S. Factors Influencing Students' Intention To Use Mobile Learning:A Study at Yemen Higher Education Institutions. In Proceedings of the 2021 2nd International Conference on Smart Computing and Electronic Enterprise (ICSCEE), Virtual, 15-17 June 2021; pp. 206-211.

116. Alshurideh, M.; Al Kurdi, B.; AlHamad, A.; Salloum, S.; Alkurdi, S.; Dehghan, A.; Abuhashesh, M.; Masa'Deh, R. Factors Affecting the Use of Smart Mobile Examination Platforms by Universities' Postgraduate Students during the COVID-19 Pandemic: An Empirical Study. Informatics 2021, 8, 32. [CrossRef]

117. Delone, W.H.; McLean, E.R. Information Systems Success: The Quest for the Dependent Variable. Inf. Syst. Res. 1992, 3, 60-95. [CrossRef]

118. Al-Rahmi, A.M.; Shamsuddin, A.; Alturki, U.; Aldraiweesh, A.; Yusof, F.M.; Al-Rahmi, W.M.; Aljeraiwi, A. AThe Influence of Information System Success and Technology Acceptance Model on Social Media Factors in Education. Sustainability 2021, 13, 7770. [CrossRef]

119. Alturas, B. Models of Acceptance and Use of Technology Research Trends: Literature Review and Exploratory Bibliometric Study. Intell. Transp. Syst. 2021, 13-28. [CrossRef]

120. McKinney, V.; Yoon, K.; Zahedi, F. “Mariam” The Measurement of Web-Customer Satisfaction: An Expectation and Disconfirmation Approach. Inf. Syst. Res. 2002, 13, 296-315. [CrossRef] 